\title{
Prospects for the use of calcium ammonium nitrate on acidic soils of the Non-Black Earth Area
}

\author{
N. I. Akanova ${ }^{1}$, M. M. Vizirskaya ${ }^{1}$, and V. Yu. Zhdanov ${ }^{2, *}$ \\ ${ }^{1}$ All-Russian research institute of agrochemistry named after D.N. Pryanishnikova", 31A, \\ Pryanishnikova st., Moscow, 127550, Russia \\ ${ }^{2}$ Business school of Russian State University for Humanities, Miusskaya sq. 6, Moscow, 125993, \\ Russia
}

\begin{abstract}
The results of the effectiveness of the application of calcium ammonium nitrate (CAN) in winter wheat crops of the "Moskovskaya-39" variety on the dark-gray forest, heavy-loamy soil in the Ryazan region is presented. The advantage of CAN-a a universal form of nitrogen fertilizer, which has a neutral reaction and creates optimal conditions for feeding plants with nitrogen in the zone of its application, where the main mass of plant roots is located, is revealed. Along with nitrogen, fertilizer contains calcium and magnesium, which are essential for the formation of winter wheat productivity, the exchange of carbohydrates and proteins. In the field experience with winter wheat on soils not saturated with bases, the results were obtained, indicating the effectiveness of a physiologically neutral form of nitrogen fertilizer, which showed an advantage over physiologically acidic fertilizer - ammonia nitrate. Dynamics of the formation of the productivity of sowing showed that the area of leaves reached the maximum sizes by the flowering phase of $61.6-76.6 \mathrm{~cm}^{2} /$ plant, the largest value of the indicator $76.6 \mathrm{~cm}^{2} /$ plant was in the variant with the use of CAN feeding at a dose of $54 \mathrm{~kg} / \mathrm{ha}$ of nitrogen. The use of CAN provided a reliable increase in the harvest of winter wheat grain in comparison with ammonium nitrate. The grain harvest in the experiment was 63.7 - 67.1 cents per hectare, statistically close were the values of yield in variants using CAN in doses of 68 and $54 \mathrm{~kg} / \mathrm{ha}$ of nitrogen, the increase in the harvest was 3.8-5.3\% respectively. The creation of optimal conditions for winter wheat during the growing season was accompanied by an improvement in the quality of the grain, in comparison with the variant with the use of ammonium nitrate.
\end{abstract}

In modern economic conditions, the sustainable and effective development of agricultural production is inextricably linked with the use of mineral fertilizers, primarily nitrogen, due to which significant increases in the yield of crops are obtained. Calcium ammonium nitrate, as well as calcium nitrate, is a fertilizer that is widely used in agricultural production. With its systematic application, the soil is enriched with calcium, which leads to a decrease in the acidity of the soil solution and an improvement in the physical and

\footnotetext{
* Corresponding author: vasilii.zhdanov@gmail.com
} 
chemical properties of the soil. This property allows the use of CAN on various types of soils, especially effective on sod-podzolic medium and slightly acidic soils [1].

The indisputable advantage of CAN is the presence in its chemical composition, in addition to nitrogen, of calcium and magnesium carbonates, which cause an increase in the efficiency of non-root fertilization of crops on both acidic and alkaline soils, as well as on soils of light granulometric composition (sandy, sandy loam) and saline [2,3]. The use of CAN not only increases the supply of plants with such elements of mineral nutrition as nitrogen and calcium but also contributes to the preservation of soil fertility and the creation of sustainable agriculture.

In the development of grain farming, the priority direction is to increase the production of winter wheat grain and improve its quality, this is the most realistic way to increase the resources of food and feed protein $[4,5]$. One of the main and controlled methods for improving the technology of winter wheat cultivation is the scientifically based use of mineral fertilizers, taking into account soil and climatic conditions and the physiological needs of plants, which makes it possible to significantly increase the yield and harvest of plant proteins [6-7].

Along with nitrogen, phosphorus, and potassium, an important physiological role of calcium for the formation of winter wheat productivity has been established. Calcium participates in the metabolism of carbohydrates and protein substances, provides favorable conditions for the development of the root system, and actively affects the protoplasm and its colloidal-chemical properties [8-9].

Winter wheat in the Russian Federation occupies a leading position among grain crops, including, in comparison with spring wheat, and is characterized by a higher and more stable yield. Among the grain crops, winter wheat is the most demanding for the level of mineral nutrition. It consumes about $10 \mathrm{~kg}$ of calcium per 1 ton of grain, and there may be a lack of it due to the increased yield and increased removal from the soil [10]. When there is a lack of calcium, as a rule, there is a slime of root cells, the absorption of nutrients from the soil is disrupted, the growth of leaves is delayed, they appear chlorotic - light yellow spots, which leads to the death of leaves [11].

When improving the fertilizer system, the issues of plant nutrition with calcium were not given much importance, and mainly highly concentrated species containing mainly $\mathrm{N}, \mathrm{P}, \mathrm{K}$ are used [12]. This leads to an increase in calcium in agrocoenosises, including in chernozems, which will naturally have a negative impact on the yield and quality of winter wheat grain [13].

Against the background of the use of highly concentrated unbalanced mineral fertilizers, extremely low application of organic and lime fertilizers, a negative balance of calcium in the soil is formed [14]; therefore, the search for methods of activating physiological processes that provide an increase in protein synthesis in plants and an increase in protein content without reducing grain productivity is not only relevant but also promising [15].

The purpose of the research was to study the effectiveness of the use of various doses of CAN in non-root top dressing on winter wheat crops of the "Moskovskaya-39" variety on the dark gray forest, heavy loamy soil in the Ryazan region. Agrochemical indicators of the site's soil are presented in Table 1.

Table 1. Agrochemical indicators of dark gray forest heavy loamy soils before laying the experiment

\begin{tabular}{|c|c|c|c|c|c|c|c|}
\hline \multirow{2}{*}{$\begin{array}{l}\text { Depth, } \\
\text { cm }\end{array}$} & \multirow{2}{*}{$\begin{array}{c}\text { Humus, } \\
\%\end{array}$} & \multirow[t]{2}{*}{$\mathrm{rN}_{\text {sal }}$. } & \multirow{2}{*}{$\begin{array}{c}\mathrm{N} \text { total., } \\
\%\end{array}$} & $\mathrm{P}_{2} \mathrm{O}_{5}$ & $\mathrm{~K}_{2} \mathrm{O}$ & Нг & $\mathrm{S}$ \\
\hline & & & & \multicolumn{2}{|c|}{$\mathrm{mg} / 100 \mathrm{~g}$ of soil } & \multicolumn{2}{|c|}{$\mathrm{mg} \cdot \mathrm{eq} / 100 \mathrm{~g}$ of soil } \\
\hline $0-20$ & 4,09 & 5,6 & 0,21 & 20,3 & 13,96 & 1,69 & 27,6 \\
\hline
\end{tabular}


The scheme of the experiment was built according to the method of organized repetitions, the repetition is 4-fold. In the experiment, a comparative assessment of the effectiveness of CAN (nitrogen content of 27\%) with ammonium nitrate (nitrogen content of 34\%) was carried out. As background, in autumn (NPC)60 fertilizers were introduced in the form of nitrophosk NPK =16-16-16 (375 kg/ha by weight). Mineral fertilizers were applied for pre-sowing cultivation of KPS-4 with simultaneous embedding according to the variants. Nitrogen fertilizing with ammonium nitrate and CAN was carried out after the fixation of the VNVV (the time of the beginning of the spring vegetation of winter wheat). The agricultural technology of winter wheat cultivation corresponded to the zonal recommendations. All studies, including the assessment of the quality of the grain of the resulting crop, were carried out under GOST. Sowing of winter wheat "Moskovskaya-39" was carried out with the SZ - 5,4 A - 0,6 seeder, according to the generally accepted technology of cultivation of the crop. The seeding rate is 5.5 million/ha of germinating grains. At the time of sowing, the soil moisture in the layer of $0-30 \mathrm{~cm}$ was $16.8 \%$.

The growth and development of winter wheat were greatly influenced by the climatic conditions of the 2019-2020 experiment. In general, they were favorable for their growth and development.

Winter wheat plants in the fall of 2019 developed in conditions of high temperatures and lack of moisture. In total, $78.9 \mathrm{~mm}$ of precipitation fell during the autumn growing season, which is $15 \%$ of the long-term average values. Despite such conditions, visually, the crops in the autumn period were assessed as good. The scheme of the experiment consisted of 4 variants:

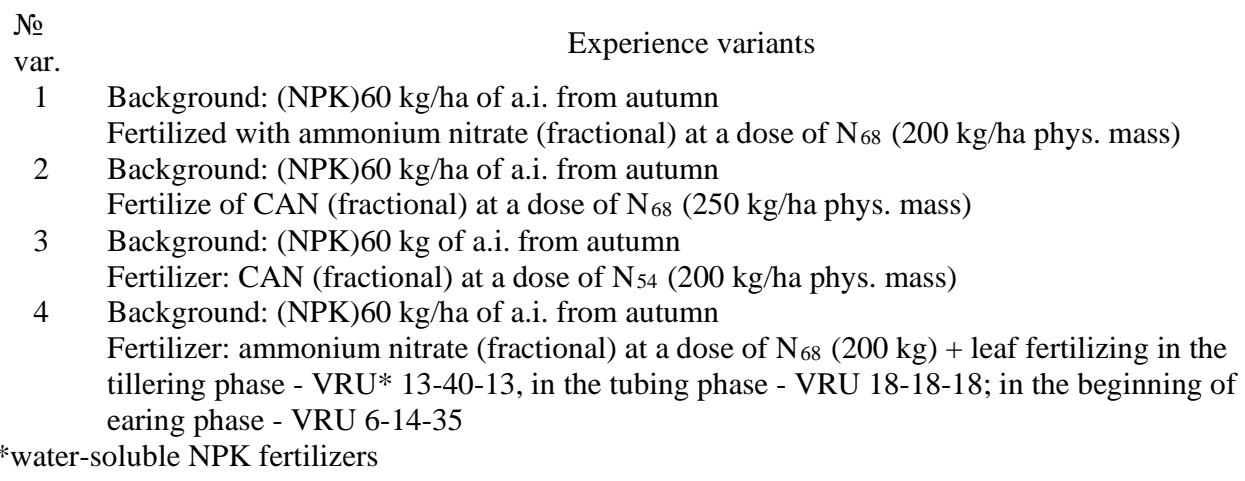

\section{Discussion of research results}

Spring nitrogen fertilization had a great influence on tillering, increasing the number of stems with an ear (Table 2).

Table 2. Productive bushiness of winter wheat "Moskovskaya-39"

\begin{tabular}{|c|c|c|c|}
\hline Variant & $\begin{array}{c}\text { Number of plants per 1 } \\
\mathrm{m}^{2} \text { 10.29.19. }\end{array}$ & $\begin{array}{c}\text { Number of stems per } 1 \\
\mathrm{~m}^{2}, 05.20 .20 \mathrm{~g} \cdot \mathrm{pcs} / \mathrm{m}^{2}\end{array}$ & Tillering ratio \\
\hline 1. & 431 & 1480 & 3,43 \\
\hline 2. & 449 & 1788 & 3,98 \\
\hline 3. & 458 & 1760 & 3,84 \\
\hline 4. & 453 & 1812 & 4,00 \\
\hline
\end{tabular}

Wheat plants on the variants with top dressing formed a more powerful root system and were bushier. There were no differences in overwintering in the experimental variants. The plant density by seedling varied from 431 on variant No. 1 with ammonium nitrate to 458 $\mathrm{pcs} / \mathrm{m}^{2}$ on variant No. 3 with CAN. The coefficient of productive bushiness of wheat ranged from 3.43 to 4.0 . The maximum number of productive stems of winter wheat was obtained 
in variant No. 4-4.0, and in variant No. 3-3.84. The increase in the number of stems was in variants No. 2 and 4 - 16\%, № 3 -12\%.

Questions of the nitrogen regime of soils, diagnostics of the need of plants for nitrogen are not sufficiently studied. The main source of nitrogen nutrition of plants in the field is nitrate and ammonia nitrogen (Table 3). As a result of the conducted studies, it was found that the reserves of nitrate and ammonium nitrogen in the soil in the variants vary slightly, but no significant differences were found.

Table 3. The content of nitrate and ammonium nitrogen in the phase of exit into the tube, depending on the top dressing with nitrogen fertilizers, $\mathrm{mg} / \mathrm{kg}$ of soil

\begin{tabular}{|c|c|c|}
\hline \multirow{3}{*}{ Variant } & $\begin{array}{c}\mathrm{N}_{3} \text { (nitrate nitrogen) } \\
05.12 .20 \mathrm{~g} .\end{array}$ & $\begin{array}{c}\text { N-NH} \\
\text { (ammonia nitrogen) } \\
\end{array}$ \\
\cline { 2 - 3 } & & $05.12 .20 \mathrm{~g}$. \\
\hline 1. & 23,3 & 3,58 \\
\hline 2. & 22,3 & 3,55 \\
\hline 3. & 22,2 & 3,42 \\
\hline 4. & 18,1 & 3,76 \\
\hline
\end{tabular}

CAN is a physiologically neutral fertilizer, so on acidic soils, it may have advantages over the widely used, physiologically acidic ammonium nitrate. The study of biometric indicators of winter wheat plants showed that the weight of the aboveground part of the plants did not differ much in the tubulation phase in the experimental variants; however, by the time of flowering, better plant development was noted in variants 2,3 , and 4 . The height of plants in the same variants increased significantly, by $15.5 \mathrm{~cm}, 22.4,9.7 \mathrm{~cm}$, respectively, compared to the variant where ammonium nitrate was used.

Table 4. Biometric parameters of winter wheat

\begin{tabular}{|c|c|c|c|c|c|c|}
\hline \multirow{2}{*}{ Variant } & \multirow{2}{*}{$\begin{array}{c}\text { Number of } \\
\text { stems, pcs/1 } \mathrm{m}^{2}\end{array}$} & \multicolumn{2}{|c|}{ Weight of 1 plant, g } & \multicolumn{2}{|c|}{ Plant height, cm } & \% of dry \\
\cline { 3 - 6 } & tubing & flowering & $05.12 .20 \mathrm{y}$. & $6.08 .20 \mathrm{y}$. & matter \\
\hline 1. & 1480 & 12,0 & 30,8 & 33,8 & 67,1 & 16,9 \\
\hline 2. & 1988 & 13,9 & 63,0 & 35,4 & 87,6 & 16,0 \\
\hline 3. & 1860 & 13,3 & 60,0 & 32,7 & 89,5 & 16,6 \\
\hline 4. & 1812 & 14,5 & 50,0 & 36,1 & 76,8 & 17,2 \\
\hline
\end{tabular}

The greatest biomass of winter wheat plants to the first date of sampling occurred in the No. 2 and No. 3 when dressing sowing aim (table. 5). When you turn on the system power of plants water-soluble fertilizers in option No. 4 marked an increase of plant biomass by $47.2 \%$ compared to the $1^{\text {st }}$ version, where fertilizer sowing was performed only ammonium nitrate.

The determination of the leaf surface area by the development phases showed that both forms of nitrogen fertilizers had a positive effect on the value of the indicator. Almost before the phase of milk ripeness, there was an increase in the leaf apparatus in all variants, which contributed to the intensive consumption of batteries.

It was found that the assimilation area in the tubulation phase was 42.4-44.0 cm2/plant according to the variants. The dynamics of the formation of crop productivity showed that the leaf area reached the maximum size by the flowering of 61.6-76.6 cm2/plant, the highest value of the indicator was in option No. 3-76.6 cm2/plant with the use of CAN top dressing at a dose of $54 \mathrm{~kg} / \mathrm{ha}$ of nitrogen. Slightly lower is the indicator of the leaf area in variant No. 2-75.2 and No. 4 - $74.5 \mathrm{~cm} 2 /$ plant (Table 6). 
Table 5. Dynamics of formation of biomass of the aboveground part of winter wheat plants "Moskovskaya-39", c/ha

\begin{tabular}{|l|c|c|c|}
\hline \multicolumn{1}{|c|}{ Variants } & $\begin{array}{c}1^{\text {st }} \text { term } \\
\text { tubeling }\end{array}$ & $\begin{array}{c}2^{\text {nd }} \text { term } \\
\text { flowering }\end{array}$ & $\begin{array}{c}\text { \% by the } \\
\text { first term }\end{array}$ \\
\hline $\begin{array}{l}\text { 1. Background: from autumn } \\
\text { Fertilizer: N68:200 kg - ammonium nitrate } \\
\text { (fractional) }\end{array}$ & 194,5 & 368,0 & 189,2 \\
\hline $\begin{array}{l}\text { 2. Background: from autumn } \\
\text { Fertilizer: N68:250 kg - CAN }\end{array}$ & 193,1 & 548,0 & 283,8 \\
\hline $\begin{array}{l}\text { 3. Background: from autumn } \\
\text { Fertilizer: N54:200 kg - CAN (fractional) }\end{array}$ & 150,9 & 454,0 & 300,9 \\
\hline $\begin{array}{l}\text { 4. Background from autumn } \\
\text { Fertilizer: N68:200 kg - ammonium nitrate } \\
\text { (fractional) + leaf fertilizing }\end{array}$ & 187,8 & 444,0 & 236,4 \\
- tillering - VRU 13-40-13 \\
- tubing VRU 18-18-18 \\
- the beginning of earing - VRU 6-14-35
\end{tabular}

Table 6. Dynamics of the formation of the leaf surface area, $\mathrm{cm}^{2} /$ plant

\begin{tabular}{|c|l|c|c|c|}
\hline \multirow{2}{*}{$\begin{array}{c}\text { № } \\
\text { p/ } \\
\text { p }\end{array}$} & \multicolumn{1}{|c|}{ Experience variants } & \multicolumn{3}{|c|}{ Phase of plant development } \\
\cline { 3 - 5 } & \multicolumn{1}{|c|}{ Tubing } & $\begin{array}{c}\text { Flow } \\
\text { ering }\end{array}$ & $\begin{array}{c}\text { Milky } \\
\text { ripeness }\end{array}$ \\
\hline 1. & $\begin{array}{l}\text { Background: NPK-60kg of a.i. from autumn } \\
\text { Fertilizer: N68:200 kg - ammonium nitrate (fractional) }\end{array}$ & 43,9 & 61,6 & 51,2 \\
\hline 2. & $\begin{array}{l}\text { Background: NPK-60kg of a.i. from autumn } \\
\text { Fertilizer: N68:250 kg - CAN (fractional) }\end{array}$ & 44,0 & 75,2 & 66,2 \\
\hline 3. & $\begin{array}{l}\text { Background: NPK-60kg of a.i. from autumn } \\
\text { Fertilizer: N54:200 kg - CAN (fractional) }\end{array}$ & 42,4 & 76,6 & 70,7 \\
\hline 4. & $\begin{array}{l}\text { Background: NPK-60kg of a.i. from autumn } \\
\text { Fertilizer: N68:200 kg - ammonium nitrate } \\
\text { fractional)+ leaf fertilizing in the tillering phase - } \\
\begin{array}{l}\text { VRU 13-40-13; in the tubing phase - VRU 18-18-18; } \\
\text { in the beginning of earing phase - VRU 6-14-35 } \\
\text { fractional) }\end{array}\end{array}$ & 42,7 & 74,5 & 69,3 \\
\hline & HCP05 & 2,3 & 5,9 & 5,3 \\
\hline
\end{tabular}

In the phase of milk ripeness, the leaf area decreased due to the drying of the leaf tips, but there is a tendency to increase the leaf area in variants No. 2 - No. 4, the best option was the use of CAN at a dose of $54 \mathrm{~kg} / \mathrm{ha}$ of nitrogen. Due to the active growth of the leaf area to the phase of milk ripeness, the assimilation surface of winter wheat plants was greater in the variants with the use of CAN by 1.3-1.4 times, in variant No. 4, the indicator was also 1.4 times higher compared to the $1^{\text {st }}$ variant; however, in comparison with the first measurement, the top dressing of CAN crops in the $2^{\text {nd }}$ and $3^{\text {rd }}$ variants in different doses contributed to an increase in the leaf area by 1.51-1.67 times, in the $4^{\text {th }}$ variant using water-soluble fertilizersby 1.62 times. For comparison, we note that fertilizing the crop with only ammonium nitrate in the $1^{\text {st }}$ variant provided an increase in the leaf area by 1.16 times.

The use of various types of nitrogen fertilizers in top dressing caused a change in the chemical composition of wheat plants: the concentration of nitrogen in the $2^{\text {nd }}$ and $3^{\text {rd }}$ variants increased, in variant No. 4 the content of potassium significantly increased (Table 7). The use of various nitrogen fertilizers did not affect the phosphorus content. 
Table 7. Chemical composition of winter wheat plants

\begin{tabular}{|c|c|c|c|}
\hline \multirow{2}{*}{ Variant } & \multicolumn{3}{|c|}{ Content, \% (in terms of dry matter) } \\
\cline { 2 - 4 } & $\begin{array}{c}\text { Nitrogen } \\
\text { GOST 32044.1-2012 }\end{array}$ & $\begin{array}{c}\text { Phosphorus } \\
\text { GOST 26657-97 }\end{array}$ & $\begin{array}{c}\text { Potassium } \\
\text { GOST 30504-97 }\end{array}$ \\
\hline 1. & 2,27 & 0,28 & 1,09 \\
\hline 2. & 2,58 & 0,27 & 1,02 \\
\hline 3. & 2,48 & 0,28 & 0,99 \\
\hline 4. & 2,39 & 0,28 & 1,23 \\
\hline
\end{tabular}

The structure of the crop is a biological model of the yield of any agricultural crop, showing what elements it consists of. The results of the sheaf analysis showed that the use of CAN contributed to an increase in the length of the ear (options 2 and 3), there is a tendency to increase the water content of the ear and the weight of grain from 1 ear (options 2, 3), the weight of 1000 grains (options 2, 3, 4). The use of top dressing VRU (var. 4) contributed to an improvement in the safety of the side stems by $6.7 \%$ in comparison with the $1^{\text {st }}$ variant, where ammonium nitrate was used for top dressing (Table 8).

Table 8. Structure of the "Moskovskaya-39" winter wheat crop

\begin{tabular}{|c|c|c|c|c|c|c|c|c|}
\hline \multirow{2}{*}{$\begin{array}{c}\text { Varia } \\
\text { nt }\end{array}$} & \multirow[b]{2}{*}{$\begin{array}{c}\text { Plant } \\
\text { height, } \\
\mathrm{cm}\end{array}$} & \multicolumn{2}{|c|}{ Quantity of pcs/1 $\mathrm{m}^{2}$} & \multirow[b]{2}{*}{$\begin{array}{c}\text { Ear } \\
\text { length, } \\
\text { cm }\end{array}$} & \multicolumn{2}{|c|}{ Quantity per ear, pcs. } & \multicolumn{2}{|c|}{ Weight, g } \\
\hline & & of plants & of stems & & of ears & of seeds & $\begin{array}{l}1000 \\
\text { seeds }\end{array}$ & $\begin{array}{l}\text { seeds } \\
\text { from the } \\
1^{\text {st }} \text { ear }\end{array}$ \\
\hline 1. & 110,9 & 220 & 752 & 8,2 & 32,5 & 34,2 & 40,8 & 1,24 \\
\hline 2. & 111,7 & 240 & 736 & 8,4 & 33,8 & 34,7 & 41,9 & 1,35 \\
\hline 3. & 112,9 & 234 & 744 & 8,7 & 35,0 & 35,9 & 43,8 & 1,42 \\
\hline 4. & 108,9 & 218 & 802 & 7,6 & 32,5 & 33,0 & 42,0 & 1,28 \\
\hline
\end{tabular}

The change in the values of the main elements of the structure of the winter wheat crop, due to the use of nitrogen fertilization by various types of fertilizers, affected the final yield of winter wheat grain (Table 9).

Table 9. The effect of nitrogen fertilization on the winter wheat crop, c/ha

\begin{tabular}{|c|c|c|c|}
\hline \multirow[t]{2}{*}{ № of Variant } & \multirow{2}{*}{$\begin{array}{l}\text { Seed yield, } \\
\text { c/ha }\end{array}$} & \multicolumn{2}{|c|}{ \pm to the $1^{\text {st }}$ variant } \\
\hline & & c/ha & $\%$ \\
\hline $\begin{array}{l}\text { 1. Background: from autumn } \\
\text { Fertilizer: } \mathrm{N}_{68}: 200 \mathrm{~kg} \text { - ammonium nitrate } \\
\text { (fractional) }\end{array}$ & 63,7 & - & - \\
\hline $\begin{array}{l}\text { 2. Background: from autumn } \\
\text { Fertilizer: } N_{68}: 250 \mathrm{~kg} \text { - CAN }\end{array}$ & 67,1 & 3,4 & 5,3 \\
\hline $\begin{array}{l}\text { 3. Background: from autumn } \\
\text { Fertilizer: } N_{54}: 200 \mathrm{~kg} \text { - CAN (fractional) }\end{array}$ & 66,1 & 2,4 & 3,8 \\
\hline $\begin{array}{l}\text { 4. Background from autumn } \\
\text { Fertilizer: N68:200 kg - ammonium nitrate } \\
\text { (fractional) + leaf fertilizing } \\
\text { - tillering - VRU 13-40-13 } \\
\text { - tubing VRU 18-18-18 } \\
\text { - the beginning of earing - VRU 6-14-35 }\end{array}$ & 66,8 & 3,1 & 4,9 \\
\hline $\mathrm{HCP}_{05}$ & 0,72 & & \\
\hline
\end{tabular}

The yield of winter wheat in the experiment was 63.7-67.1 c/ha. The yield values were statistically similar in the variants with the use of CAN (2 and 3 var) and VRU (4 var). The use of CAN provided an increase in grain yield by 3.8-5.3 \% compared to the $1^{\text {st }}$ option, and the use of VRU in the $4^{\text {th }}$ option by $4.9 \%$. 
The assessment of the quality of wheat grain showed that in the conditions of 2020 when using different types of nitrogen fertilizers, there were no significant differences in the content of st arch, protein, gluten, and the value of IDC; however, the grain nature in variants 2, 3, and 4 decreased (Table 10).

Table 10. Nature and chemical composition of winter wheat grain

\begin{tabular}{|c|c|c|c|}
\hline \multirow{2}{*}{ Variant } & \multicolumn{3}{|c|}{ Content, \% (in terms of dry matter) } \\
\cline { 2 - 4 } & $\begin{array}{c}\text { Nitrogen } \\
\text { GOST 32044.1-2012 }\end{array}$ & $\begin{array}{c}\text { Nitrogen } \\
\text { GOST 32044.1-2012 }\end{array}$ & $\begin{array}{c}\text { Nitrogen } \\
\text { GOST 32044.1-2012 }\end{array}$ \\
\hline 1. & 2,27 & 0,28 & 1,09 \\
\hline 2. & 2,58 & 0,27 & 1,02 \\
\hline 3. & 2,48 & 0,28 & 0,99 \\
\hline 4. & 2,39 & 0,28 & 1,23 \\
\hline
\end{tabular}

Evaluation of the effectiveness of CAN on winter wheat crops of the "Moskovskaya39 " variety showed that the highest gross profit of 40,702 rubles was obtained in the $2^{\text {nd }}$ variant, where CAN was applied to top dressing at a dose of $68 \mathrm{~kg} / \mathrm{ha}$ of nitrogen. In the $3^{\text {rd }}$ and $4^{\text {th }}$ versions of the experiment, where CAN was used at a dose of $54 \mathrm{~kg} / \mathrm{ha}$ of nitrogen and VRU, a similar gross profit was obtained - 39022 and 39324 rubles, respectively. Profitability, also the greatest- $154.2 \%$ was noted in the conditions of a top dressing of CAN in the maximum dose in the $2^{\text {nd }}$ variant. The reduction of the dose of CAN in the $3^{\text {rd }}$ variant and the use of VRU provided similar profitability indicators - 144, and 143.1\%.

\section{Conclusion}

A comparative assessment of the effectiveness of calcium ammonium nitrate with traditional nitrogen-ammonium nitrate on winter wheat crops of the "Moskovskaya-39" variety on dark gray forest heavy-loamy soil indicates that CAN with non-root fertilization of the crop during the growing season had an advantage in its effect on plant development and the formation of grain yield. The grain yield in the variants with the use of CAN at doses of 68 and $54 \mathrm{~kg} / \mathrm{ha}$ of nitrogen was statistically similar in value, the increase was 3.8-5.3\% compared to the variant where ammonium nitrate was used.

\section{References}

1. Taran A.L., Dolgaliv E.V., Taran Yu.A. (2006) Getting lime-ammonium nitrate in the pellet towers produced by ammonium nitrate / Chemical technique. - № 1. P. 28-31.

2. Kiss A.S. (1961) Fertilizer production data - ammonium nitrate with the addition of dolomite. The exchange reaction between the ammonium nitrate melt and the addition of dolomite or limestone is added ... Magyar kem. lapja. T. 16, No. 2. - P. 63-65. RJHim 1961, $21 \mathrm{~K} 81$.

3. Havkin E.E. (1987) Prospects for the use of lime-ammonium nitrate and selenium / Chemistry in agriculture. T. 25, No. 6. - P. 77-79.

4. Abuzov V.V., Grechyshkina I.I. (2010) Productivity of winter wheat on black earth when fed by various forms of nitrogen fertilizers / Fertility, No.1 - P.17-18.

5. Zavalin A.A., Saffron S.A., Chernova L.S., Dubrovskiy L.N. (2009) New form of nitrogen fertilizer under spring wheat/Fertility -No1.- P.19-20

6. Agafonov E.V., Gromakov A.A., Maximenko M.V. (2012) Application of complex fertilizers and nitrogen fertilization under winter wheat / 16 p. 
7. Torikov V.E., Fokin I.I. (2011) Yield, quality of winter wheat grain depending on growing conditions and norms of mineral fertilizer application / Problems of agrochemical and ecology, No. 2. - P. 50-54.

8. Shilnikov I.A., Sichev V.G., Sheujen A.H., Akanova N.I., Bondareva T.N., Kizinyok S.V. (2012) Loss of plant food elements in the agrobiogeochemical cycle of substances and ways to minimize them. Monograph. VNIIA, $351 \mathrm{p}$.

9. Shilnikov I.A., Sichov V.G., Sheujen A.H., Akanova N.I. (2015) Loss of plant nutrients. Monograph. Published: Lambert Academic Publishing, OmniScriptum GmbH Co.KG, Deutschland - 502 p.

10. Mineev V.G. (2004) Agrochemistion. - M.: Colossus, - S. 720. Peterburgskiy A.V. (1981) Agrochemistion and plant nutrition physiology. - M.: Rosselkhozizdat, $2^{\text {nd }}$ ed. $184 \mathrm{p}$.

11. Peterburgskiy A.V. (1981) Agrochemistry and physiology of plant nutrition. - Moscow: Rosselkhoizdat, $2^{\text {nd }}$ ed., rew., - 184 p.

12. Torikov V.E., Melnikova O.V., Spilev N.S., et. al. (2012) Yield, adaptive potential, and quality of grains of winter wheat varieties / Fruits and berry growing of Russia, No. 2. - P. 318-333.

13. Glychyshkina Y.V. (2020) Preservation and reproduction of the fertility of black earth soils to increase the productivity of agrocenosis of the Central Precaucasus. Author. Doct. diss., M.: VNIA, - 48 p.

14. The Reima A.M., Namazov Sh.S., Seytnazarov A.R., Beglov B.M., Nabiev A.A., Aymbetov M.J. (2017) Calcium ammonium nitrate and its application in agriculture//Universum: Technical Sciences - № 6 (39). - Pp. 6-13.

15. Akanova N.I., Vizirka M.M. (2019) Application of nitrogen Fertilizers and limestone in agricultural production. A scientific and practical guide. M: VNIIA - 28 p.

16. Dospekhov B.A. (1985) Methodology of field experience (with the basics of statistical processing of research results). $-5^{\text {th }}$ ed., add. and rew. - M.: Agropromizdat, - $351 \mathrm{p}$. 